\title{
1. Introduction to Teaching Entrepreneurship, Volume Two
}

\author{
Heidi M. Neck, Candida G. Brush and \\ Patricia G. Greene
}

Now more than ever our role as educator is to unleash the entrepreneurial spirit of our students, cultivate a mindset of practice, and build environments in which practice can occur. In turn our students can lead more entrepreneurial lives because of their newly found bias for action, appreciation for learning through action, and comfort with ambiguity. (Neck et al., 2014, p. 1)

In 2014 we published the first volume of Teaching Entrepreneurship: $A$ Practice-Based Approach writing directly in response to the calls from around the world for more experiential entrepreneurship education. These calls largely reflected the belief that in order to learn entrepreneurship, we must do entrepreneurship. Our first volume was so well received that it broke sales records and was translated into Spanish and Chinese. The response from educators was overwhelmingly positive because it provided a much-needed resource to create more experiential and engaging learning environments for entrepreneurship students. Therefore, our imperative, then and now, is that as entrepreneurship educators we need to focus not only on what we teach, but on how we teach. To this end, in Volume One we presented five key practices related to entrepreneurship education play, creation, empathy, experimentation, and reflection - that directly link to students thinking and acting entrepreneurially. We then presented Exercises connected to these practices.

When we wrote Volume One, alternative ways for teaching entrepreneurship were starting to take hold. These approaches were grounded in the critical importance of doing entrepreneurship, acting entrepreneurially or being entrepreneurial. During this time, lean startup (Ries, 2011; Blank, 2013 [2020]; Blank and Dorf, 2012 [2020]) and design thinking (Dunne and Martin, 2006; Brown, 2009; Sarooghi et al., 2019) emerged on the west coast of the United States. Entrepreneurial thought and action (Greenberg et al., 2011; Schlesinger and Kiefer, 2012) and disciplined entrepreneurship (Aulet, 2013) emerged on the east coast. Effectuation 
theory (Sarasvathy, 2008) was embraced globally but was most popular in Europe. The common theme across most entrepreneurship education approaches that have emerged since we first published Volume One in 2014 is that entrepreneurship requires "a practice-based approach as a model of learning to support entrepreneurial action" (Neck et al., 2014, p. 13) to embrace uncertainty, move forward in the face of ambiguity, to test in order to learn, and to reflect in and on practice. It is wonderful to see that the field of entrepreneurship education has converged on a broad, yet powerful, theme of practice that both guides us as educators and differentiates us a field. Since Volume Two, Neck et al.'s (2020) awardwinning textbook, Entrepreneurship: The Practice and Mindset, Second Edition, has been widely adopted because it supports entrepreneurship as both a practice and mindset while using the frameworks of all the aforementioned approaches. We happily acknowledge there is no one best way of teaching and learning entrepreneurship.

We have been humbled by the distribution, elated by the feedback, and evaluative of our own thinking since we first introduced the five practices of entrepreneurship education: play, creation, empathy, experimentation,

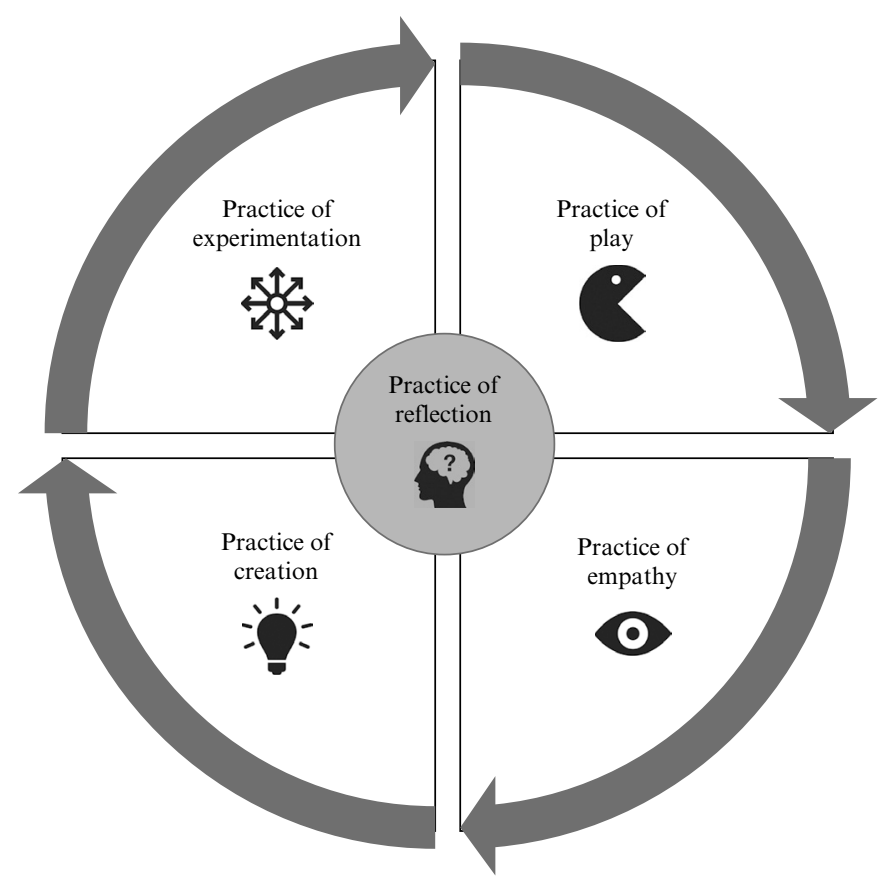

Figure 1.1 The five practices of entrepreneurship education 
and reflection (see Figure 1.1).Volume Two is a reflection on, and extension of, our first volume. The purpose of Volume Two is the same as that of Volume One: we want to advance entrepreneurship education for all types of students using an action-based method rooted in a specific set of practices. Volume One delved into the theory behind the five practices and offered 42 teaching Exercises related to the practices. In this volume we briefly revisit the five practices, address the latest thinking in entrepreneurship education and, most importantly, offer a new set of 43 Exercises that connect to the five practices. We, along with 29 of our Babson colleagues are excited to share another batch of diverse, experiential Exercises, complete with detailed teaching notes, to help educators teach entrepreneurship more entrepreneurially using the five practices. Also, as in Volume One, each of these Exercises has already been student tested and many are adaptable to an online environment. As far as we know, no students were harmed in our testing!

We also believe that the relevancy of these five practices has grown since we first published in 2014. As we learned and applied our five practices more frequently, we increasingly recognized their connection with and contribution to developing an entrepreneurial mindset among our students. As a consequence, we concluded that the latest research in entrepreneurship education supports our work to an even greater degree now than it did in 2014.

\section{ENTREPRENEURSHIP EDUCATION AND THE ENTREPRENEURIAL MINDSET}

Research has supported that being entrepreneurial can be learned over time (Busenitz and Barney, 1997; Sarasvathy, 2008), but it is also widely accepted that nascent entrepreneurs, such as our students, require practice and experience to feel entrepreneurial and build the mindset required to identify and act on opportunities (Baron and Ensley, 2006; Baron and Henry, 2010; Cohen et al., 2020a; 2020b). Entrepreneurship education research over the past seven years has catapulted the notion of an entrepreneurial mindset as a most desired learning outcome across business and non-business disciplines. Yet, a single, unifying definition and measurement of the entrepreneurial mindset has eluded researchers to date, which has created a wonderful and fertile area of inquiry and academic conversation (Haynie et al., 2010; Davis et al., 2016; Neck and Corbett, 2018; Kuratko et al., 2020).

Stanford psychology professor, Carol Dweck, a prominent researcher of students' mindsets in early education, asserts that how students per- 
ceived themselves significantly affected their motivation and achievement (Dweck, 2012). She states that "mindsets frame the running account that's taking place in people's heads" (Dweck, 2015, p. 25). This perspective on mindset relating to how we view the world makes sense here because that frame, similar to an empty and transparent picture frame, is what we are looking through as we observe, interpret, and make decisions in our perceived world. So, then the question becomes, how do we move from our current mindset to a more entrepreneurial mindset? Perhaps it is not a matter of viewing the entrepreneurial mindset as a concrete state that is measurable, but more of a "mindshift" - moving from one level of thinking, acting and being to the next level. An important assumption, then, is that every student may have a different starting point and a different ending point. The change in thinking becomes more important than what constitutes the actual thinking. The resulting change may be a perceptual measurement as determined by the student.

Our concept of entrepreneurial mindshift as a change in a student's current mindset to a more entrepreneurial mindset requires practice $-\mathrm{a}$ journey into "a way of thinking, acting, and being that combines the ability to find or create new opportunities with the courage to act on them" (Neck et al., 2020, p. 3). The practice that is necessary to generate a mindshift change in students is facilitated by educators using the practice-based methodology we introduced in Volume One and continue to emphasize in Volume Two, albeit expanded based on the manner in which our approach has evolved through our own practice as educators. We contend that if educators use the five practices in their teaching, students will shift their current way of thinking to one that is more entrepreneurial, then they can begin building the requisite courage and confidence to act on new opportunities.

\section{THE PRACTICES OF ENTREPRENEURSHIP EDUCATION REVISITED ${ }^{1}$}

We grounded our first volume of Teaching Entrepreneurship in the notion that entrepreneurs practice being entrepreneurial to gain confidence and courage to take action under conditions of high uncertainty and ambiguity. The premise holds here for our second volume. We, as entrepreneurial educators, can facilitate entrepreneurial development through pedagogies rooted in five practices of entrepreneurship education (see Figure 1.1).

1 This section is a summary of the practices published in Volume One of Teaching Entrepreneurship: A Practice-Based Approach (Neck et al., 2014). 
Each practice is grounded in actionable theories from across disciplines, and together constitute a method of thinking and acting entrepreneurially regardless of context.

Practice theory (cf. Giddens, 1984; Bourdieu, 1990; Pickering, 1992; Rouse, 2007) stems from the belief that particular types of learning activities can "generate richer understanding about practice, but from and through practice, not on behalf of it" (Billet, 2010, p.29). There has been growing interest in using practice theory in entrepreneurship research (Chalmers and Shaw, 2017; Antonacopoulou and Fuller, 2020; Thompson et al., 2020), but the emphasis thus far has been on practice concerning how entrepreneurs get things done. Our approach to practice is more traditional, emphasizing doing in order to develop habits - particularly as they relate to developing a more entrepreneurial way of thinking and being. Furthermore, we build on the definition of practice as "the enactment of the kinds of activities and interactions that constitutes the occupation" (Billett, 2010, p. 22) using the predominant theoretical themes found (Rouse, 2007) to promote a practice-based approach to entrepreneurship education:

1. Practices are meaningful performances governed by social rules and norms.

2. Practices create culture and act as a platform for social construction.

3. Practices require continuous interaction with others and/or the environment, leading to expanded knowledge structures and mindfulness in the practice.

4. Practices create shared meaning among participants through the use of language, frameworks, tools, and common experiences.

5. Practice creates habits in both actions and ways of thinking.

There is no single practice of entrepreneurship education. It requires a complex and multidisciplinary approach, so our suggested portfolio of practices is designed to lead to a more holistic teaching approach with a desired outcome to help students think and act more entrepreneurially. Thus, there are five core practices of entrepreneurship education: the practice of play; the practice of empathy; the practice of creation; the practice of experimentation, and the practice of reflection. Volume One delved deeply into the theory behind the five practices, thus what follows is a brief overview of each practice.

\section{The Practice of Play}

"The practice of play is about developing a free and imaginative mind, allowing one to see a wealth of possibilities, a world of opportunities, 
and a pathway to more innovative ways of being entrepreneurial" (Neck et al., 2014, p. 25). We all, not just students, learn best when we are highly engaged, and we are typically more engaged when we are having fun while being playful. Yet the words fun and play are not often associated with higher education. The irony is that the connection between play and education is so taboo that an entire gaming category had to be labeled "serious games" (Abt, 1970) to denote those games playable for education purposes only. We subscribe to Kafai's (1995) philosophy that "Learning is at its best when it is deadly serious and very playful at the same time" (p. 314).

There are three forms of play that represent different cognitive levels. First, sociodramatic play is based on imagination and fantasy. Guiding entrepreneurship students through creative Exercises where mundane ideas are transformed into magical ideas in order to eventually get to a novel opportunity is an example of sociodramatic play. Second, functional play requires interacting with the environment. Take, for example, the popular business model canvas (Osterwalder and Pigneur, 2010). In Volume One, we introduced a card game using the nine components of the business model canvas. Student teams are given a deck of nine cards with each card having one business model component. The teams are required to put the components in order from the most important component to the least important under time constraints. This type of card game is an example of functional play because students are physically moving cards around and discussing each part of the business model canvas while competing with other teams for the "correct" order. Third, Constructive play encourages students to build, create, or problem solve. The "Marshmallow tower," described in Volume One, and "The Babson Airplane Company," in this volume, are examples of constructive play - students using various materials to build and test solutions.

These three forms of play encourage students to physically interact with entrepreneurship concepts rather than learn passively. Engaging students in playful learning experiences can also lead to the elusive outcomes of getting students outside of their comfort zone and overcoming fears. For us, however, the use of play in entrepreneurship education is also culture building as we work with intention to design robust communities of learning in our courses.

\section{The Practice of Empathy}

Empathy is "a social and emotional skill that helps us feel and understand the emotion, circumstances, intentions, thoughts, and needs of 
others, such that we can offer sensitive, perceptive, and appropriate communications and support" (McLaren, 2013, p. 11). Empathy can be developed over time by creating experiences or scenarios where this skill can be honed (Kouprie and Visser, 2009). Preston and de Waal (2002) found that empathy increases with, for example, familiarity, similarity, past experience, and salience, which supports the notion that empathic development requires practice.

The practice of empathy is important in entrepreneurship education for two primary reasons. First, students need to develop empathy by understanding the lives of the entrepreneurs they want to become. The "Interviewing an entrepreneur" Exercise presented in Volume One helps students develop empathy for a practicing entrepreneur while also assessing their own ability to become an entrepreneur. Second, empathy allows students to connect with stakeholders in more meaningful and authentic ways in order to identify unmet needs - the antecedent of new products, services, and organizations. The "AEIOU observation" Exercise in this volume encourages students to watch, listen, and feel what is happening in a particular environment, be it a grocery store, sporting event, peaceful protest, or even a Zoom meeting. The popularity of design thinking in entrepreneurship education (Hug and Gilbert, 2017; Sarooghi et al., 2019; Dunne and Martin, 2006) is evidence that empathic development is a critical practice to incorporate into our courses. IDEO's three phases of design thinking, inspiration, ideation, implementation (Brown, 2008) certainly had a role in many of the Exercises used in Volume One. Our readers will see these themes continue in some of the Exercises in this volume.

\section{The Practice of Creation}

Inspired by effectuation theory (Sarasvathy, 2008) and creativity theorists (Amabile, 1983, Csikszentmihalyi, 1996; de Bono, 1985), the practice of creation relates to unleashing the creative ability of students to produce something of value with what they have rather than not producing because of constraints based on what they think is needed. This practice is multifaceted and includes creating and finding opportunities, problem solving, searching opportunity spaces, idea generation, and a general openness to the world. Sarasvathy's groundbreaking theory on effectuation $(2001,2008,2012)$ is the ideal starting point because effectual entrepreneurs create opportunities, not simply find or look for opportunities. Developing a practice of creating opportunities is based on the following principles (Sarasvathy, 2008; Dew et al., 2009; Neck, 2010; Schlesinger and Keiffer, 2012): 
1. Desire to act precedes everything else. Without an avid desire to learn, insatiable curiosity, and unyielding energy, it is difficult to sustain and shape opportunities in the long run.

2. A perceived lack of resources is an easy excuse to rationalize inaction. Creation requires that students start with what they have rather than what they need. Effectuation theory encourages students to answer three basic questions: "Who am I?," "What do I know?," and "Whom do I know?" The answers to these questions help students calculate the personal assets they have to start something immediately. Through action, the resources and subsequent opportunity will grow over time.

3. Enrolling others in the idea (not selling or pitching) requires collaboration rather than competition. Sharing ideas and building a network of enrolled stakeholders will ultimately increase the resource base, validate the idea, and expand the possibilities available.

4. Calculating what you are willing to lose (affordable loss) to take steps forward is more empowering than estimating a highly variable internal rate of return. Small steps in the beginning cost very little (money, time, and reputation) but also build priceless confidence.

5. Expect and leverage failure. The "F" word is too often ignored in entrepreneurship classrooms but failure is both inevitable and a given. Learning from failure is a given, but how to learn from failure is a slippery slope. In the practice of creation, we are mostly referring to small actions and therefore small failures, so learning from failure and leveraging that new knowledge is important. ${ }^{2}$

The above five components encourage students to act under conditions of extreme ambiguity and uncertainty, without complete information, to create something new of value. Furthermore, the roadblocks of creativity, such as fear and perceived constraints, are overcome.

Volume Two introduces eight new Exercises in this category, yet we also recognize that many Exercises in this volume touch on multiple practices concurrently. For example, in this volume we reimagined our popular "Puzzles and quilts" Exercise from Volume One for an online class session. The updated version, called "Puzzles and stories," is classified under the practice of play, but it clearly exposes students to the practice of creation and highlights the differences between managerial and entrepreneurial thinking as presented in Saras Sarasvathy's effectuation work.

2 Shepherd (2004) addresses more devastating types of failure and offers interesting examples of how to help students deal with business failure. He incorporates theory from death and grief education. 


\section{The Practice of Experimentation}

Experimentation, in entrepreneurship education, borrows from theories related to problem-based learning (Barrows, 1985), evidence-based learning (Howard et al., 2003), and sensemaking (Weick, 1995). Problem-based learning induces cognitive conflict as a stimulus for learning, and evidencebased learning encourages the use existing information, though often incomplete, as a starting point for generating new knowledge. Then, sensemaking is a combination of problem-based and evidence-based learnings because students individually "make sense" of or "give meaning" to their actions in the context of the environments. According to Weick (1995, p.50), sensemaking is "an ongoing accomplishment that emerges from efforts to create order and make retrospective sense of what occurs." So it is through experimentation, regardless of how it is done, that students are encouraged to act, learn from that action, and building the learning into the next iteration (Schlesinger and Kiefer, 2012; Neck et al., 2020).

The practice of experimentation is best described as students acting in order to learn rather than learning before acting or applying. Tools such as Babson's methodology of Entrepreneurial Thought \& Action ${ }^{\circledR}$ (Schlesinger and Kiefer, 2012; Neck et al., 2020) as taught in Babson's Symposium for Entrepreneurship Educators, Lean Launchpad (Blank and Dorf, 2012 [2020]; Blank, 2013 [2020]), the Business Model Canvas (Osterwalder and Pigneur, 2010), and the Innographer Toolkit (Bruton, 2020) all require actions through experimentation, getting out of the building, and collecting new and real information as opposed to depending on Google searches or rich university databases to test new concepts. With every new idea and opportunity comes an associated set of assumptions and questions. The practice of experimentation encourages students to validate every assumption and answer every question.

Strong experiments have a clear purpose and should generate reliable results. In Volume One, the "Escalating market tests" Exercise was a clear example of how to teach students to test small in order to grow large. Given the importance of this topic, we included a slightly revised version of this Exercise in this volume.

We also expand our definition of experimentation to include students grappling with new topics and trying out new concepts. For example, we address gender acumen and the role gender differences play in how we approach entrepreneurship (see "Building gender acumen as an inclusive entrepreneurial leadership competence). Additionally we look at how small changes in supply chains can reduce negative impacts on the environment (see "Supply chain innovation to reduce ecological impact"). 


\section{The Practice of Reflection}

The final practice of reflection is situated in the center of Figure 1.1 because it both connects and enriches the other practices. A practice of reflection requires metacognition - a practice of thinking about thinking in order to codify one's learning (Schraw and Dennison, 1994). Given the action orientation of all the previous practices, reflection is used here as another action but one that helps make sense of the other actions required in the practices of play, empathy, creation, and experimentation.

The theoretical foundations of this practice are from Schön's reflective practitioner work (1983) and Brockbank and McGill's (2007) dense and rigorous treatment of reflection in higher education. The purpose of reflection is to go beyond surface learning into deep learning - "an active approach to learning, and a desire to get a grasp of the main point, make connections and draw conclusions" (Brockbank and McGill, 2007, p. 42) in order for entrepreneurship students to "feel themselves to be the agents of learning" (Marton, 1975, p. 137). Schön addresses "reflectionon-practice" and "reflection-in practice" as important to an ongoing cycle of learning from and during experiences. Brockbank and McGill (2007, pp. 126-7), and adapted by Neck et al. (2014), offer different six types of reflection that we included in Volume One. We suggested then, as we do now, that these forms of reflection can solicit and solidify learning from an action-orientated, practice-based approach to entrepreneurship education:

1. Narrative reflection: describe what happened.

2. Emotional reflection: focus on what you were feeling, why, and how the emotions were managed.

3. Percipient reflection: think about the perceptions (yours and others) and how it affected the experience.

4. Analytical reflection: explain the processes or important elements of the events, how they are connected or related.

5. Evaluative reflection: assess the experience and identify the criteria used for the evaluation.

6. Critical reflection: consider the experience and approach, identify alternatives or contradictions as well as reflecting on what was learned about yourself in the process.

Each type of reflection represents a different level of depth and cognitive complexity. For example, a narrative reflection is much easier for a student to accomplish than a critical reflection. We suggest scaffolding your reflection practice as your courses increase in complexity across the course of the 
semester or program. Volume Two has eight new Exercises related to the practice of reflection. These Exercises, by design, are more introspective. For example, the "Envisioning your future" Exercise requires students to imagine a future point in time, and the "Looking in" Exercise helps students grapple with the less talked about role of identify in new venture creation. Though there are distinct Exercises for reflection in this volume, we suggest incorporating one or more of the six types of reflection into every experiential Exercise used.

\section{HOW TO USE THE FIVE PRACTICES OF ENTREPRENEURSHIP EDUCATION}

The five practices have become a framework for course development and stand separate from the competencies we need to develop in our students. They are our development method - a way of teaching designed to help students progress their thinking in a more entrepreneurial manner, leading to a mindshift that includes a heightened level of courage with the associated skillset to act on opportunities under conditions of uncertainty. We started using the five practices framework to ensure that our educational programs led students to think and act more entrepreneurially after they left our courses than when they started. This approach now also guides our consulting on course and curriculum development, as we encourage educators to use individual Exercises, group activities, simulations, games, projects, field trips, and other experiences that connect to one or more practices. From our experience, we now know that if we can choreograph a course to apply each of the five practices at multiple times and some at the same time, then students will leave the course thinking and acting more entrepreneurially.

Let's use a course that both Heidi Neck and Candida "Candy" Brush teach as an example. They teach an MBA level "Intro to entrepreneurship" course. The seven-week course is a journey through the fuzzy front-end of early stage entrepreneurial activity; it is not intended to be a complete overview of entrepreneurship. The learning objectives include:

- Experience Babson's methodology of Entrepreneurial Thought \& $\operatorname{Action}^{\circledR}$ (ET\&A).

- Differentiate between entrepreneurial and managerial thinking.

- Practice ideation methods to help you better create and shape ideas into bold opportunities.

- Evaluate opportunities using iterative, fast-paced analyses designed for quick learning to support on-the-go adjustments. 
- Develop, analyze, and clearly communicate the feasibility, viability, and desirability of a possible new business concept.

\section{Table 1.1 The practices applied}

\begin{tabular}{ll}
\hline Practice & Exercises \\
\hline Play & $\begin{array}{l}\text { Sailing boat; Puzzles and stories; Business model card game; } \\
\text { Food truck challenge simulation; Revenue model scavenger } \\
\text { hunt; T-shirt slogan night }\end{array}$ \\
Need-finding interviews; observation assignment; guest \\
speaker; feedback interviews; podcast report; opportunity \\
analysis project \\
Quilts and puzzles; Low fidelity prototypes; Mind dump; \\
Creation & $\begin{array}{l}\text { lean canvas development; opportunity analysis project } \\
\text { Market tests; Food truck challenge simulation; prototyping } \\
\text { Experimentation }\end{array}$ \\
& $\begin{array}{l}\text { Exercise; Ideaspace; opportunity analysis project } \\
\text { Food truck challenge simulation; Mindshift Exercises; } \\
\text { Mindset vitamins; simulation discussion board; customer } \\
\text { feedback interviews; podcast report }\end{array}$ \\
\hline
\end{tabular}

Note: Many Exercises connect to more than one practice. Balance across the practices is important. Some of the teaching notes for these Exercises can be found in Volume One and others in this volume.

Underlying the necessary learning objectives that must be reported on a syllabus, the teaching goal is to ensure that students leave the course thinking and acting more entrepreneurially. The topics in the course include ET\&A, idea generation, design thinking, business model generation, low fidelity or rapid prototyping, market tests, customer development, and networking - the norms in a typical introduction course. Heidi and Candy, however, crafted all Exercises and assignment using the five practices framework (Figure 1.1). Table 1.1 shows how each activity used in the course connects to one or more of the five practices.

In a recent course survey, Heidi inserted the following statement: "I believe I am thinking and acting more entrepreneurially after taking this course." The responses available to the students were "yes," "no," or "unsure." Eighty-six percent stated yes, 14 percent were unsure, and 0 percent said no. How many students? Forty-seven. Scientific? Absolutely not, but we feel we are moving in the right direction, and students' perception is their reality. 


\section{THE ORGANIZATION OF VOLUME TWO}

This book is a tool for entrepreneurship educators of all types. There are 43 teaching notes organized by primary practice. We say primary practice because, as seen in Table 1.1, Exercises are often connected to more than one practice. Chapter 3 is devoted to Exercises to practice play. Chapter 4 is devoted to Exercises to practice empathy. Chapter 5 is devoted to Exercises to practice creation. Chapter 6 is devoted to Exercises to practice experimentation. Finally, Chapter 7 is devoted to Exercises to practice reflection. Iconography is used with each Exercise. The first icon indicates the primary practice while the icons that follow are secondary practices. The icons listed in Table 1.2 are used.

In addition to the practices, the Exercises cross a number of entrepreneurship topics including business model development, customer development, design thinking (including prototyping), entrepreneurial finance, entrepreneurial marketing, teams, failure, ideation, market or competitive analysis, mindset, networking, opportunity evaluation, pitching, resource acquisition, scale and managing growth, and testing. As a result, you can you use the Appendix at the end of the book to search for Exercises by topic. We believe that most of Exercises can be applied to multiple contexts, including new venture creation, corporate entrepreneurship, and social entrepreneurship; therefore, these contexts are not treated as topics. Two Exercises, however, are focused specifically on the context of family entrepreneurship. Each teaching note is designed to give you enough detail to conduct the Exercise in class. We also suggest the class format, such as online, face to face, or both. We made a concerted effort in this volume to include Exercises that can work online. Finally, pay special attention to the "Teaching Tips" section of each teaching note. All of the Exercises in this volume have been tested by Babson faculty. We hope you benefit from our mistakes!

\section{Table 1.2 Practice icons}

\begin{tabular}{ll}
\hline Icon & Practice \\
\hline 0 Play \\
8 Empathy \\
Creation \\
(2) Experimentation \\
\hline
\end{tabular}


Before moving to the Exercises, however, we have a fun, reflective activity awaiting you in Chapter 2 to help you take stock of your own approach to entrepreneurship education and identify how you might already be using the practices presented here in your current teaching.

\section{REFERENCES}

Abt, C.C. (1970), Serious Games, New York: Viking Press.

Amabile, T.M. (1983), 'The social psychology of creativity: a componential conceptualization', Journal of Personality and Social Psychology, 45 (2), 357-76.

Antonacopoulou, E.P. and T. Fuller (2020), 'Practising entrepreneuring as emplacement: the impact of sensation and anticipation in entrepreneurial action', Entrepreneurship \& Regional Development, 32 (3-4), 257-80.

Aulet, B. (2013), Disciplined Entrepreneurship: 24 Steps To a Successful Startup, Marblehead, MA: John Wiley \& Sons.

Baron, R.A. and M.D. Ensley (2006), 'Opportunity recognition as the detection of meaningful patterns: evidence from comparisons of novice and experienced entrepreneurs', Management Science, 52 (9), 1331-44.

Baron, R.A. and R.A. Henry (2010), 'How entrepreneurs acquire the capacity to excel: insights from research on expert performance', Strategic Entrepreneurship Journal, 4 (1), 49-65.

Barrows, H. (1985), 'A taxonomy of problem based learning methods', Medical Education, 20 (6), 481-6.

Billett, S. (ed.) (2010), Learning through Practice, New York: Springer.

Blank, S. (2013), The Four Steps to the Epiphany: Successful Strategies for Products that Win, repr. 2020, Marblehead, MA: John Wiley \& Sons.

Blank, S. and B. Dorf (2012), The Startup Owner's Manual: The Step-By-Step Guide For Building A Great Company, repr. 2020, Marblehead, MA: John Wiley $\&$ Sons.

Bono, E. de (1985), Six Thinking Hats, New York: Little Brown.

Bourdieu, P. (1990), The Logic of Practice, Stanford, CA: Stanford University Press.

Brockbank, A. and I. McGill (2007), Facilitating Reflective Learning in Higher Education, London: McGraw-Hill Education.

Brown, T. (2008), 'Design thinking', Harvard Business Review, June, 84-92.

Brown, T. (2009), Change By Design: How Design Thinking Transforms Organizations and Inspires Innovation, New Yorker: Harper Collins.

Bruton, A. (2020), 'The innographer', accessed 4 August 2020 at https://theinnogra pher.com/.

Busenitz, L.W. and J.B. Barney (1997), 'Differences between entrepreneurs and managers in large organizations: biases and heuristics in strategic decisionmaking', Journal of Business Venturing, 12 (1), 9-30.

Chalmers, D.M. and E. Shaw (2017), 'The endogenous construction of entrepreneurial contexts: a practice-based perspective', International Small Business Journal, 35 (1), 19-39.

Cohen, D., D.K. Hsu and R.S. Shinnar (2020a), 'Identifying innovative opportunities in the entrepreneurship classroom: a new approach and empirical test', 
Small Business Economics, 30 July, 1-25, accessed 1 August 2020 at https://linkspringer-com.ezproxy.babson.edu/article/10.1007/s11187-020-00387-z\#citeas.

Cohen, D., G. Pool and H. Neck (2020b), The IDEATE Method: Identifying HighPotential Entrepreneurial Ideas, Thousand Oaks, CA: Sage.

Csikszentmihalyi, M. (1996), Creativity Flow and the Psychology of Discovery and Invention, New York: Harper Collins.

Davis, M.H., J.A. Hall and P.S. Mayer (2016), 'Developing a new measure of entrepreneurial mindset: reliability, validity, and implications for practitioners', Consulting Psychology Journal: Practice and Research, 68 (1), 21-48.

Dew, N., S. Read, S.D. Sarasvathy and R. Wiltbank (2009), 'Effectual versus predictive logics in entrepreneurial decision-making: differences between experts and novices', Journal of Business Venturing, 24 (4), 287-309.

Dunne, D. and R. Martin (2006), 'Design thinking and how it will change management education: an interview and discussion', Academy of Management Learning \& Education, 5 (4), 512-23.

Dweck, C. (2012), Mindset: Changing the Way You Think to Fulfil Your Potential, London: Hachette UK.

Dweck, C. (2015), 'Carol Dweck revisits the growth mindset', Education Week, 35 (5), 20-24.

Giddens, A. (1984), The Constitution of Society, Berkeley, CA: University of California Press.

Greenberg, D., K. McKone-Sweet and H.J. Wilson (2011) The New Entrepreneurial Leader: Developing Leaders Who Shape Social and Economic Opportunity, San Francisco, CA: Berrett-Koehler.

Haynie, J.M., D. Shepherd, E. Mosakowski and P.C. Earley (2010), 'A situated metacognitive model of the entrepreneurial mindset', Journal of Business Venturing, 25 (2), 217-29.

Howard, M.O., C.J. McMillen and D.E. Pollio (2003), 'Teaching evidence-based practice: toward a new paradigm for social work education', Research on Social Work Practice, 13 (2), 234-59.

Hug, A. and D. Gilbert (2017), 'All the world's a stage: transforming entrepreneurship education through design thinking', Education + Training, 59 (2), 155-70.

Kafai, Y.B. (1995), Minds in Play: Computer Game Design as a Context for Children's Learning, Hillsdale, NJ: Lawrence Erlbaum Associates.

Kouprie, M. and F.S. Visser (2009), 'A framework for empathy in design: stepping into and out of the user's life', Journal of Engineering Design, 20 (5), 437-48.

Kuratko, D.F., G. Fisher and D.B. Audretsch (2020), 'Unraveling the entrepreneurial mindset', Small Business Economics, 17 June, 1-11, accessed 1 August 2020 at https://link-springer-com.ezproxy.babson.edu/article/10.1007\% 2Fs11187-020-00372-6.

Marton, F. (1975), 'What does it take to learn?', in N.J. Entwistle (ed.), Strategies for Research and Development in Higher Education, Amsterdam: Swets \& Zeitlinger, pp. 125-5-8.

McLaren, K. (2013), The Art of Empathy, Boulder, CO: Sounds True.

Neck, H.M. (2010), 'Idea generation', in B. Bygrave and A. Zacharakis (eds), Portable MBA in Entrepreneurship, Hoboken, NJ: Wiley, pp. 27-52.

Neck, H.M. and A.C. Corbett (2018), 'The scholarship of teaching and learning entrepreneurship', Entrepreneurship Education and Pedagogy, 1 (1), 8-41.

Neck, H.M., P.G. Greene and C.G. Brush (eds) (2014), Teaching Entrepreneurship: 
A Practice-Based Approach, Cheltenham, UK and Northampton, MA, USA: Edward Elgar.

Neck, H.M., C.P. Neck and E.L. Murray (2020), Entrepreneurship: The Practice and Mindset, 2nd edn, Thousand Oaks, CA: Sage.

Osterwalder, A. and Y. Pigneur (2010), Business Model Generation: A Handbook for Visionaries, Game Changers, and Challengers, Marblehead, MA: John Wiley \& Sons.

Pickering, A. (1992), Science as Practice and Culture, Chicago, IL: University of Chicago Press.

Preston, S.D. and F.B.M. De Waal (2002), 'Empathy: its ultimate and proximate bases', Behavioral and Brain Sciences, 25 (1), 1-20.

Ries, E. (2011), The Lean Startup: How Today's Entrepreneurs Use Continuous Innovation to Create Radically Successful Businesses, New York: Crown.

Rouse, J. (2007), 'Practice theory', in S. Turner and M. Risjord (eds), Philosophy of Anthropology and Sociology, Amsterdam: North-Holland, pp. 639-81.

Sarasvathy, S.D. (2001), 'Causation and effectuation: toward a theoretical shift from economic inevitability to entrepreneurial contingency,' Academy of Management Review, 26 (2), 243-63.

Sarasvathy, S.D. (2008), Effectuation: Elements of Entrepreneurial Expertise, Cheltenham, UK and Northampton, MA, USA: Edward Elgar.

Sarasvathy, S. (2012), 'Worldmaking', in A.C. Corbett and J.A. Katz (eds), Entrepreneurial Action, Bingley: Emerald, pp. 1-24.

Sarooghi, H., S. Sunny, J. Hornsby and S. Fernhaber (2019), 'Design thinking and entrepreneurship education: where are we, and what are the possibilities?', Journal of Small Business Management, 57 (S1), 78-93.

Schlesinger, L.A. and C.F. Kiefer, with P.B. Brown (2012), Just Start: Take Action, Embrace Uncertainty, Create the Future, Cambridge, MA: Harvard Business Review Press.

Schön, D.A. (1983), The Reflective Practitioner: How Professionals Think in Action, New York: Basic Books.

Schraw, G. and R.S. Dennison (1994), 'Assessing metacognitive awareness', Contemporary Educational Psychology, 19 (4), 460-75.

Shepherd, D.A. (2004), 'Educating entrepreneurship students about emotion and learning from failure', Academy of Management Learning \& Education, 3 (3), 274-87.

Thompson, N.A., K. Verduijn and W.B. Gartner (2020), 'Entrepreneurship-aspractice: grounding contemporary theories of practice into entrepreneurship studies,' Entrepreneurship \& Regional Development, 32 (3-4), 247-56.

Weick, K.E. (1995), Sensemaking in Organizations, Thousand Oaks, CA: Sage. 